\title{
INTEGRATED WATER MANAGEMENT IN THE REPUBLIC OF BULGARIA - STATUS AND PRIORITIES
}

\begin{abstract}
The Republic of Bulgaria has adopted the basic principles of water management policy laid down in Directive 2000/60/EC of the European Parliament. The main focus of this policy is to meet the needs of water in the quantity and quality necessary for the needs of economic sectors and especially for the manufacture of agricultural products.

The study indicates that application of the integrated water resource management is an approach that achieves not only the environmental objectives with regard to the aquatic ecosystems, but also a coordinated management of waters, land and the vital ecosystems.

The condition of water management in Bulgaria was examined at a national and basin level. It was found that the river basins determined in the Water Act do not follow the administrative and territorial division of the country. The management of aquaculture systems is carried out on technological and basin principle in accordance with the terms and conditions of the permits for water use and use of water units for different economic activities.
\end{abstract}

Keywords: water management, Republic of Bulgaria, agricultural products.

JEL Codes: Q15, Q25, Q28.

\section{Introduction}

The Ministry of the Environment and Waters (MEW) implements the state policy in the sphere of integrated and sustainable water management in a quantitative and qualitative aspect, it coordinates, regulates, balances and controls the industrial and territorial policies related to water in order to meet the needs and to keep the water resources for future generations. 
The basic principles, on which water management in the Republic of Bulgaria, is based are:

- Integrated management - complexity, environmental efficiency, effectiveness, priority;

- River basin - a basic unit for water management;

- Hierarchy of management;

- Alternatives and effectiveness of management;

- Legislative compliance of the adopted management principles;

- Science service and application of a systematic approach;

- Participation of public and the local authorities.

The main purpose of this article is to present the integrated water management in the Republic of Bulgaria, to explore and analyse its status and to identify the basic priorities.

\section{Material and methods}

The study was carried out by means of presenting and analysing the regulatory acts in the field of water management.

For the purpose of the study the following were examined: Water Act, Directive 2000/60/EC of 23 October 2000 of the European Parliament and of the Council establishing a framework for the Community action in the field of water policy (EU Water Framework Directive) as well as the Report of the Commission to the European Parliament and the Council on the implementation of the water framework directive $(2000 / 60 / \mathrm{EC})$. The study of the legislative framework of the European Community and Republic of Bulgaria is related to the conservation of water resources.

\section{Results and discussions}

The basic principles for the implementation of the rational use of water resources in Bulgaria are in full compliance with the aim pursued for achieving maximum consistency between the water management policy implemented in the country and the accepted principles of sustainable water policy in the European Community laid down in Directive 2000/60/EC (Directive..., 2000), namely:

- Implementation of a coordinated and integrated water policy in the Republic of Bulgaria at a ministerial level with clearly set out responsibilities in accordance with the terms and requirements of the Water Framework Directive in order to adopt and further develop common principles and structures for the protection and sustainable use of waters;

- Ensuring appropriate coordination between the various ministries and with the neighbouring countries for control of transboundary impacts in the river basins occurring as a result of the use of waters;

- Establishment of river basin as the basic unit for the joint management of water resources (surface and underground waters); 
- Achieving sustainable water use and conservation of water resources in accordance with the principle of improving the ecological status of surface waters and ensuring good status of underground waters;

- Taking preventive actions to give priority to the elimination of environmental damages at their source;

- Complete implementation of the "polluter pays" principle and recovery of the full costs for services in the water sector, including expenditures for environmental and water resources protection;

- Implementation of economic regulators aimed at promoting sustainable use of water and aquatic environment;

- Compliance with the principles of solidarity and respect for the public interest by ensuring concerted actions and cooperation at all levels of management;

- Information security and inclusion of the general public, including the users of water services, in the discussion processes and making long-term decisions and adoption of action programmes;

- Integration of the principles of water conservation and sustainable water use in different sectors and fields such as power engineering, industry, agriculture, fisheries, regional policy, etc.;

- Establishing mechanisms to encourage the use of new technical achievements for economical water consumption and improving the efficiency of existing aquaculture systems and facilities.

On 21.11.2012 the National Assembly of the Republic of Bulgaria adopted the National strategy for management and development of water sector (2012) covering the period until 2037, which sets out the main objectives, stages and methods of development.

To achieve the above objectives and principles for water management the following was adopted:

1. Single management at a national level of the natural resource "water".

2. Determination of a single water management at a river basin level or a river basin group level. The disputes and transfers of water between river basins shall be decided by the State authority at the national level.

3 . The level "Aquaculture system" is governed by economic laws, but within the limits laid down by the basin level in compliance with the principles of effective, rational, economical and complex use of water resources.

Policies relating to achieving an integrated approach to water management are based on the understanding that water resources are of public interest with nationwide long-term strategic importance to the country.

Integrated water management requires:

1. Development and implementation of a national policy for water management as a single and indivisible national resource on the basis of natural river basins, etc., basin management principle; 
2. A uniform national policy for the management and development of the combination of aquaculture systems and facilities;

3. Clear regulations and application of a uniform national policy regarding the public-legal regime for the use of waters and aquatic environment and the public-legal nature of the ownership over the aquaculture systems and facilities;

4. A uniform national policy regarding the economic regulation of water sector and financing its development.

5. Information which shall be made available to the public about the completion of the objectives according to the defined progress indicators, about the progress achieved and the benefits to the society (Figure 1).

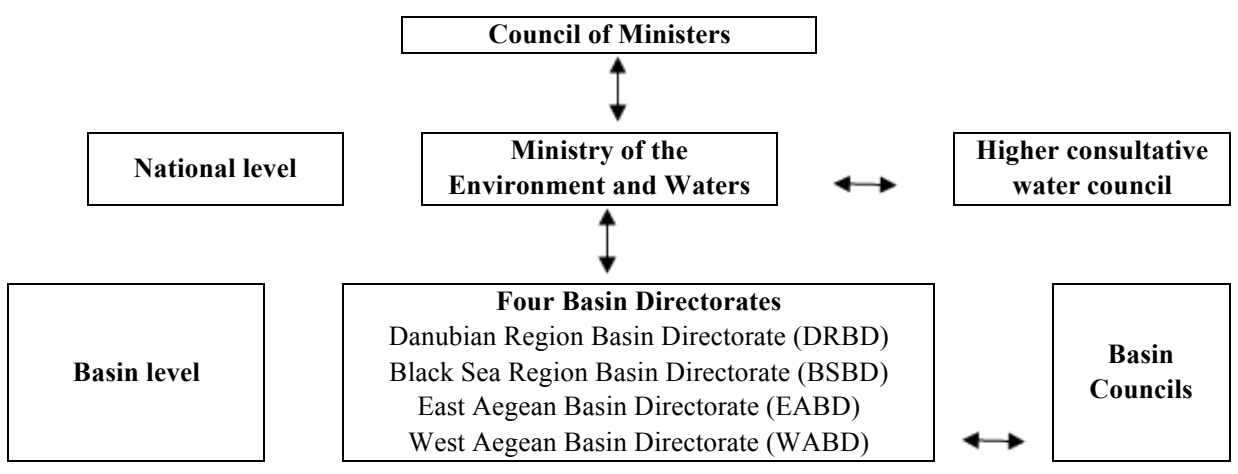

Fig. 1. Water management.

Source: Ministry of the Environment and Waters - Bulgaria: Water Management Directorate.

Basin principle of water management is the modern and efficient approach to water management, both in national and in cross-border territorial scope.

In an inter-institutional aspect however, the integrated water management requires improvement in coordination of policies and activities between institutions both at national and basin levels.

With the adoption of the Water Act, basin principle of water management has been introduced. In 2002, four river basin directorates were established in accordance with the basin water management regions (Article 152(1) of the WA (2015)).

Practically speaking, though, basin directorates began functioning in 2003. Their establishment, administrative completion and structuring helped to overcome a significant institutional obstacle to the introduction of the integrated water management principle at basin level. The establishment of these administrative structures has ensured the performance of core functions in accordance with the legislation in force. 


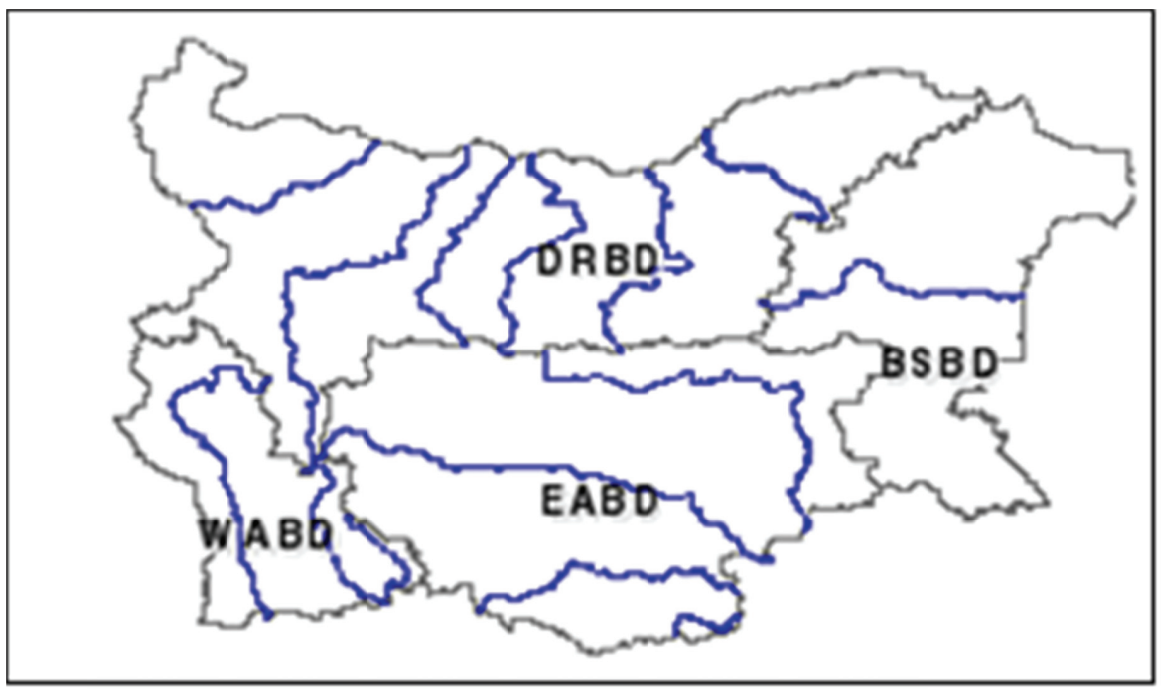

Fig. 2. Territory of the basin directorates.

Source: Ministry of Environment and Water - Bulgaria.

The territory of the Republic of Bulgaria is divided into four basin water management regions based on the river basin principle.

For each water management region the competent body is the Basin Directorate (Figure 2).

The Danubian region, which has its centre in the city of Pleven - is responsible for the Bulgarian part of the Danube River and its tributaries.

The Black Sea region, which has its centre in the city of Varna - is responsible for the Bulgarian part of the aquatory of the Black Sea and its tributaries.

The East Aegean region, which has its centre in the city of Plovdiv - is responsible for the catchment of the rivers Maritsa, Tundzha, Arda and Byala.

The West Aegean region, which has its centre in the city of Blagoevgrad - is responsible for the catchment of the rivers of Struma, Mesta and Dospat.

Basin directorates carry out water management at a basin level and they issue all permits for water use and use of the aquatic environment, except for those issued by the Minister of the Environment and Waters, they also perform the activity of the national system for water monitoring at a basin level, including the water quantity monitoring.

They develop the plans for management of the respective pool, they maintain and keep at a basin level the specialised aquaculture cards, water registers, water bodies and aquaculture systems and facilities, as well as the registers of licenses issued; they prepare documentation for compulsory collection of fees for water use and pollution; they monitor the compliance with the conditions and requirements set forth in the issued licenses; they carry out supervision of 
instrumentation and control devices of hydro-technical facilities; they manage the waters - an exclusive state property, which are not granted to concession; they establish sanitary zones, etc.

The river basin management plans (RBMPs) are an essential tool for the water management at a basin level. They are planning documents prepared by the individual basin directorates for a period of six years. The RBMPs have the following key features (River basin..., 2016-2021):

- They play a major role in the characterisation of the basin management region regarding surface and groundwaters and the ecosystems associated with them;

- They determine water protection areas - protection areas of waters intended for human consumption, protection areas of bathing waters, areas for species conservation, such as Natura 2000, protected territories, etc., related to water;

- They analyse the pressure of human activity and assess the impact on waters and related ecosystems;

- They determine the status of surface and groundwaters, and water protection areas and provide for development of monitoring programmes;

- They formulate the objectives for environmental protection;

- They provide for preparation of programmes of measures to achieve good status of surface and groundwaters and water protection areas.

In accordance with the requirements of the Water Framework Directive the first River basin management plans are for 2010-2016 for all basin management regions, they are approved by the Minister of the Environment and Waters. They are valid until 2016, when the Plans that are prepared now will enter into force. In the new RBMPs for 2016-2021 the emphasis will be on the following main directions (River basin..., 2016-2021):

- The information in RBMPs will specify the framework for water management in different regions.

- The RBMPs are drawn up on the basis of a preliminary analysis of problem areas and provide measures to overcome them.

- The RBMPs will provide an opportunity for uniting the efforts of different national and regional structures for water management - society, local authorities, local business.

- The RBMPs will provide opportunity for wider public and businesses participation in publishing drafts of the plans.

- The actions between the structures responsible for water control and surveillance will be coordinated through RBMPs.

- The RBMPs will provide opportunities to give priority to funding and implementation of the proposed measures to tackle the problems.

Integrated water management requires a transparent, effective and coherent legal framework. By the time of its publication (1999), the Water Act played and is still playing an essential role in the regulation of social relations in the sphere 
of water sector in a contemporary way, adequate for the changes that have occurred over the last decade in the public structure.

A complete harmonized national legislation with the Community law in the field of waters was accomplished with the Water Act and the adopted regulations connected thereto.

The challenge for Bulgaria is the transposition and implementation of the Water Framework Directive 2000/60/EC, establishing the framework of the EU policy in the field of waters. A significant part of its provisions are transposed into the Water Act in force and the regulations thereto.

Full harmonization will be achieved through the development of a new Water act (Water Act, 2015; Act amending..., 2015). The following priorities will be settled in the new Act:

- the integrated management of quantity and protection of all waters as nationwide and indivisible natural resource from the harmful effects;

- introduction of the principle that water is not a commercial product like any other but it is more like a heritage which must be preserved, protected and treated as such;

- determination of the specific conditions concerning the protection of waters intended for drinking water supply of the population and the main public relations connected with the services provided;

- the requirements relating to the ecological potential of the water bodies (natural, modified, strongly modified or artificial);

- clear definition of water uses and uses which require permits, detailed criteria for the issuance or refusal thereof;

- prevention of activities that may have an adverse impact on the status of waters and aquatic ecosystems;

- the procedures for issuing permits for water use, including their facilitation in the interest of citizens;

- protection of water resources in accordance with the type of water body and the parameters which should be reached (i.e. its potential);

- protected areas related to water resources;

- prevention of water pollution from hazardous and noxious substances, including actions in the event of an accident;

- the amount and type of sanctions in case of violation of the Act;

- control to carry out the requirements of the Act;

- determining the mineral waters as an exclusive state property and the specificity when they are granted to concession, etc.

The Act regulates the participation of the general public, including water users, in the development and updating of the river basin management plans, as well as relevant information on planned measures and progress achieved in their implementation, in order to include the general public prior to the adoption of the final decision regarding the necessary measures. 


\section{Conclusions}

1. A scheme has been adopted in the Republic of Bulgaria for differentiation of the water functions in three groups: functions connected with the management of water quantity and quality; functions connected with the management of aquaculture systems and facilities; coordinating and advisory functions.

2. Complete harmonization of national legislation with the specific European directives has been achieved in the sphere of waters.

3. The Water Act of 1999 introduced the European approach to water management at a basin principle.

4. By means of laws, global and regional conventions in the sphere of water management have been ratified in the Republic of Bulgaria.

5. The integrated approach to water management in Bulgaria has been built on three legislative frameworks - international, European and national legislation.

6. The integrated management of water resources will ensure their consistent use in ways acceptable to all water users in order to achieve social and economic well-being, while at the same time the sustainability of vital ecosystems is not threatened in any way. 


\section{Literature:}

Act amending and supplementing the Water Act from 28 July 2015. Retrieved from: www. moew.government.bg.

Directive 2000/60/EC of 23.10.2000 of the European Parliament and of the Council establishing the framework of actions for the Community in the sphere of water policy (EU Water Framework Directive).

Interim review of the significant problems in water management in the East Aegean region (2014), MEW.

National strategy for management and development of water sector (2012). MEW: Sofia.

Report of the Commission to the European Parliament and the Council on the implementation of the Water framework directive (2000/60/EC). River basin management plans, 2012.

River basin management plans, 2016-2021. Essential tool for water management in Bulgaria, MEW. Retrieved from: www3.moew.government.bg.

Water Act (as last amended, No. 61 from 11.08.2015). Retrieved from: www.moew.government.bg. 
TEODORA STOEVA

EKATERINA VALCHEVA

Uniwersytet Rolniczy

Płowdiw

\title{
ZINTEGROWANA GOSPODARKA WODNA W BUŁGARII - STAN I PRIORYTETY
}

\begin{abstract}
Abstrakt
Bułgaria przyjęła podstawowe zasady polityki gospodarki wodnej określone w dyrektywie 2000/60/WE Parlamentu Europejskiego i Rady. Gtównym celem tej polityki jest zaspokojenie potrzeb $w$ zakresie zaopatrzenia $w$ wode $w$ ilości i jakości niezbędnej dla potrzeb sektorów gospodarczych, a zwłaszcza do produkcji rolnej.

Badanie wskazuje, że zastosowanie zintegrowanej gospodarki zasobami wodnymi jest podejściem, które pozwala osiagnać nie tylko cele środowiskowe w odniesieniu do ekosystemów wodnych, ale również skoordynowana gospodarke wodami, gruntami i ważnymi ekosystemami.

Stan gospodarki wodnej w Butgarii zbadano na poziomie krajowym i poszczególnych dorzeczy. Ustalono, że dorzecza określone w ustawie wodnej nie sq zgodne z podziałem administracyjno-terytorialnym kraju. Gospodarka systemami akwakultury odbywa się na bazie technologii i dorzeczy zgodnie z warunkami zezwoleń dotyczacych wykorzystania wody i użytkowania urzadzeń wodnych dla różnych rodzajów działalności gospodarczej.
\end{abstract}

Słowa kluczowe: gospodarka wodna, Bułgaria, produkty rolne.

Zaakceptowano do druku - Accepted for print: 10.04.2017.

O ile nie jest to stwierdzone inaczej, wszystkie materiały na stronie są dostępne na licencji Creative Commons Uznanie Autorstwa 3.0 Polska. Pewne prawa zastrzeżone na rzecz Instytutu Ekonomiki Rolnictwa i Gospodarki Żywnościowej - PIB.

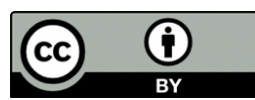

